\title{
Minor psychic disorders in nursing workers at a psychiatric hospital
}

\section{Distúrbios psíquicos menores em trabalhadores de enfermagem de um hospital psiquiátrico Trastornos psíquicos menores en trabajadores de Enfermería de un hospital psiquiátrico}

How to cite this article:

Oliveira EB, Silva SRCS, Sora AB, Oliveira TS, Valério RL, Dias LBS. Minor psychic disorders in nursing workers at a psychiatric hospital. Rev Esc Enferm USP. 2020;54:e03543. DOI: http://dx.doi.org/10.1590/S1980-220X2018031903543

\author{
Elias Barbosa de Oliveira ${ }^{1}$ \\ Silvia Regina Carvalho de Souza \\ da Silva ${ }^{2}$ \\ (D) Alcilea Barbosa de Sora
(D) Tatiane Souza de Oliveira
(D) Raphael Lopes Valério
(D) Lucas Barbosa Santos Dias \\ ${ }^{1}$ Universidade do Estado do Rio de \\ Janeiro, Faculdade de Enfermagem, \\ Departamento de Enfermagem Médico- \\ Cirúrgica, Rio de Janeiro, RJ, Brazil. \\ 2 Secretaria Municipal de Saúde do Rio \\ de Janeiro, Centro de Atenção Psicossocial \\ Rubens Corrêa, Rio de Janeiro, RJ, Brazil. \\ ${ }^{3}$ Centro Universitário Augusto \\ Motta, Enfermagem Psiquiátrica, \\ Rio de Janeiro, RJ, Brazil. \\ ${ }^{4}$ Secretaria Municipal de Saúde do Rio de \\ Janeiro, Centro de Atenção Psicossocial III - \\ Bispo do Rosário, Rio de Janeiro, RJ, Brazil. \\ ${ }^{5}$ Universidade do Estado do Rio de Janeiro, \\ Programa de Residência de Enfermagem em \\ Cardiologia, Rio de Janeiro, RJ, Brazil. \\ ${ }^{6}$ Universidade do Estado do Rio de Janeiro, \\ Programa de Residência Multiprofissional em \\ Saúde Mental, Rio de Janeiro, RJ, Brazil.
}

Corresponding author:

Elias Barbosa de Oliveira

Rua Alexandre de Gusmão, 28, Apto. 104, Tijuca

CEP 20520-120 - Rio de Janeiro, RJ, Brazil

eliasbo@oi.com.br

\begin{abstract}
Objective: To describe the frequency of suspicion of minor psychic disorders and their symptoms in nursing workers at a psychiatric hospital. Method: Cross-sectional study carried out in 2018 with nursing workers at a psychiatric hospital in the city of Rio de Janeiro, Brazil. Data were collected by using an instrument with sociodemographic, work, and health variables. The Self-Reporting Questionnaire-20 was used to verify minor psychic disorders. Results: Ninety workers participated in the study. The frequency of minor psychic disorders in the sample was equal to $32.2 \%$. The questions that showed the highest frequencies of affirmative answers were: "Do you feel nervous, tense, or worried?" (51.1\%), "Dou you often have headaches?" (41.1\%), "Is your daily working suffering?" (37.8\%), "Do you have uncomfortable feelings in your stomach?" (36.7\%), "Do you find it difficult to enjoy your daily activities?" (27.8\%), and "Are you unable to play a useful part in life?" (22.2\%). Conclusion: The predominance of symptoms of reduced vital energy and somatization suggest stress and risk of mental disorders.
\end{abstract}

\section{DESCRIPTORS}

Psychiatric Nursing; Mental Disorders; Stress Psychological; Occupational Health; Mental Health. 


\section{INTRODUCTION}

The concept of minor psychic disorders (MPD) emerged in the 1970s through the development of studies on mental disorders in the primary health care context. It refers to a set of non-psychotic symptoms, including insomnia, fatigue, irritability, forgetfulness, difficulty in concentrating, and somatic complaints. These symptoms lead to intense psychic distress and may be associated with sickness absenteeism and the reduction in work capacity, being an important public health issue $\mathrm{e}^{(1)}$.

International studies have shown that approximately $25 \%$ of the general population have psychoemotional problems at some point in life and that the prevalence of MPD varies between $24.6 \%$ and $45.3 \%$. In samples selected in Brazilian municipalities, the prevalence of MPD ranges from $17 \%$ to $35 \%$, and their occurrence may be related to multiple determinants, such as genetic, behavioral, and environmental, which combine to other factors related to gender, age group, marital status, and life and work conditions ${ }^{(2-3)}$.

According to the World Health Organization (WHO), there is a high percentage of MPD among workers from several areas, including health, resulting from occupational stress. Taking into account that nursing professionals account for a significant share of the contingent of workers in the Brazilian health network, it is relevant to investigate the suspicion of MPD in that group, given that their work is based on several activities that require a relationship with other professionals and are usually carried out under pressure, because of the cognitive and psychomotor demands these tasks make ${ }^{(3)}$.

Although the Brazilian psychiatric reform has contributed to creating new mental health care mechanisms, such as the Psychosocial Care Centers (CAPS, as per their acronym in Portuguese), the Therapeutic Residences, and other care modalities, the need for admitting patients with severe psychiatric conditions to psychiatric hospitals remains. Among the professional categories that carry out their activities in that environment, nursing is one of the most exposed to the risk of developing diseases, because of the physical and psychic workload caused by the constant need to watch and perform interventions in patients who have psychomotor agitation and pose risk of escape, self-harm, suicide, and other psychiatric emergencies ${ }^{(4)}$.

Mental health workers in Brazil face several adverse conditions resulting from the deficit in the number of professionals, in addition to insufficient material resources and infrastructure. There are also problems related to temporary employment bonds and the communication between the teams and substitute services that make up the psychosocial care network in Brazil. Other factors that can cause work-related distress are the characteristics of the users, who usually have low purchasing power, inadequate life conditions, and the fact that these people live in areas marked by violence. The scientific production about the health of workers that develop their activities in Brazilian psychiatric services, despite being undisputably relevant, is still scarce ${ }^{(5)}$.
Aiming to identify the production of articles on MPD including the participation of nursing workers, the state of the art of the field was verified by consulting the following databases: Virtual Health Library (integrated with Base de Dados de Enfermagem), Latin America and Caribbean Center on Health Sciences Information (LILACS), Medical Literature Analysis and Retrieval System Online (MEDLINE) and Cumulative Index to Nursing and Allied Health Literature (CINAHL). The expressions "disturrbios psíquicos menores", "transtornos mentais comuns", and "desordens mentais comuns" were used to perform the search on the Health Sciences Descriptors website. On PubMed, a service offered by the United States National Library of Medicine, and the CINAHL, the expressions "minor psychiatric disorders" and "common mental disorders" were searched. The article selection criteria were being available as full text, preferably in Portuguese, Spanish, or English, and having been published between 2013 and 2018 .

It was found that, despite the existence of a production of articles on common mental disorders in several areas and human groups, including nursing workers, there was a lack of studies describing the participation of professionals who work in the psychiatry field. The present study had the objective of describing the frequency of suspicion of MPD and their symptoms in nursing workers at a psychiatric hospital in order to promote a reflection on aspects related to prevention of psychosocial stress and promotion of mental health in that group of workers.

\section{METHOD}

\section{Study TYPE}

Cross-sectional study.

\section{SCEnARIo}

The study was carried out with nursing professionals (nurses, nursing technicians, and nursing aides) who worked at a medium-sized public psychiatric hospital in the city of Rio de Janeiro, state of Rio de Janeiro, Brazil.

With the implementation of the Brazilian psychiatric reform, as per Law no. 10.216 of 2001, the hospital had a significant reduction in the number of patients, which resulted in 27 beds in the male ward, 30 beds in the female ward, and eight short-stay beds. Until recently, there was the Crises Care Center, which was shut down because of the precarious working conditions.

\section{Population}

The eligible population of the present study was 103 professionals who worked at the different hospital sectors. Among them, six were excluded for being away from the workplace as a consequence of vacation or sick leave when data were collected and seven refused to participate in the study. Consequently, 90 (87.4\%) professionals answered the instruments.

The sample was all the employees who had permanent working bond (statutory), CLT (Consolidação das Leis do 
Trabalho-Brazilian law regarding work rights) or temporary work contracts and had been carrying out their care activities for at least 30 days before the beginning of data collection to meet a requirement of the Self-Reporting Questionnaire-20 (SRQ-20). Professionals who had been working at the hospital for less than 30 days, those away from work on sick leave to treat medical problems or on vacation, or refused to participate were excluded of the present study..

\section{Data Collection}

Data were collected by interviewers who were previously trained by the researcher responsible for the study. The collection team encompassed nursing undergraduate students, a master's student at the nursing graduate course, and a nurse at the hospital where the study was carried out. The team made a commitment regarding the privacy and confidentiality of the used data.

The applied instrument was made up by questions about the following independent variables: sociodemographic (gender, age group, marital status, function, level of education, and family income), occupational (contract type, whether the professional had another job, working hours, weekly working hours, and total working hours taking into account other employment bonds), health issues, use of medication, medical assistance, and work leave over the past 12 months to treat a medical condition. The dependent variable was collected by applying the SRQ-20, validated for the Brazilian context by Mari and Willians ${ }^{(6)}$ and subsequently by Gonçalves et al. ${ }^{(7)}$.

This instrument allows the early detection of signs and symptoms of mental health impairment. The Brazilian version has 20 items for the suspicion of non-psychotic mental disorders. The answer alternatives are dichotomous (yes/no), with 1 indicating that the symptoms (anxiety, reduction in vital energy, somatization, and depressive thoughts) had been present over the past month and 0 symbolizing that they were absent. The cutoff adopted for suspicion of MPD was six or more positive answers for men and eight or more for women, in accordance with the instrument manual ${ }^{(1)}$.

\section{DatA ANALYSIS AND TREATMENT}

The software used to store the collected data was Microsoft Excel, and SPSS ${ }^{\circledR}$ version 9.0 for Windows was used to perform statistical analysis. The variables related to sociodemographic, occupational, and health characteristics were examined by using descriptive statistics (absolute and relative values). Analysis of the individual frequency of symptoms was carried out by summing the positive answers of the items that made up the factors related to suspicion of MPD so as to obtain a score for each participant. In the collective examination of symptom frequency, the researchers used the number of affirmative answers for each factor and their respective complaints, considering the discussion of the symptom frequency by factor in the sample. The results were discussed from the perspective of the studies that addressed MPD in nursing and health workers, given that publications describing the examination of professionals in the psychiatry field were not found.

\section{ETHICAL ASPECTS}

After the invitation to participate in the present study and explanations about it and the scheduling, data were collected individually between May and June 2018 at the institution, at a private place. The instruments were filled out by the participants after they became aware that the study was authorized by a research ethics committee, as per Report no. 2.611.927/18 and signed a free and informed consent form. The proposal followed what is advocated by Resolution no. $466 / 12$, on studies involving human beings. The anonymity of the participants was guaranteed and it was ratified that they could withdraw their consent in any phase of the study. The importance of the workers' participation was explained, taking into consideration the lack of studies of this type in the psychiatry field and the benefits regarding institutional support to those with suspicion of MPD.

\section{RESULTS}

Initially, the participants $(\mathrm{n}=90)$ were evaluated regarding the independent variables (Table 1 ). There was a prevalence of nursing technicians, women, married people, workers from 45 to 54 years old, and a family income between three and five minimum wages. Concerning level of education, most analyzed professionals had completed high school and a significant number declared that they had a degree, although their position was at the technical level. Regarding occupational variables, $51.1 \%$ had not gone through a public tender for their current jobs (CLT or temporary employment bonds), $71.1 \%$ worked 30 hours per week and $53.3 \%$ worked more than 50 hours per week because they had more than one employment bond. According to the cutoffs established for men and women, the global suspicion of MPD was equal to $32.2 \%$. Bivariate analysis for absolute numbers showed a higher frequency of suspicion among nursing technicians, women, single professionals, older than 54 years, with complete higher education, and a family income ranging from three to five minimum wages. Concerning occupational characteristics, there was a prevalence of professionals with a statutory bond, allocated in the night shift, who had more than one job and worked more than 50 hours per week when the other employment bonds were considered.

The group of symptoms that showed the highest frequency of affirmative answers (Table 2) was the vital energy reduction one, with 151 affirmative answers (34.7\%), a result similar to that obtained for somatization, with 146 affirmative answers (33.6\%). The SRQ-20 questions with the highest number of affirmative answers were: "Do you feel nervous, tense, or worried?" (51.1\%), "Dou you often have headaches?" (41.1\%), "Is your daily working suffering?" (37.8\%), "Do you have uncomfortable feelings in your stomach?" (36.7\%), "Is your digestion poor?" (31.1\%), "Do you find it difficult to enjoy your daily activities?" (27.8\%), and "Are you unable to play a useful part in life?" (22.2\%). 
Table 1 - Distribution of nursing workers according to sociodemographic and occupational variables and suspicion of MPD Rio de Janeiro, RJ, Brazil, 2018.

\begin{tabular}{|c|c|c|c|}
\hline \multirow[b]{2}{*}{ Variable } & \multirow{2}{*}{$\begin{array}{c}\text { Sociodemographic } \\
\text { characteristics } \\
\text { n (\%) }\end{array}$} & \multicolumn{2}{|c|}{ Suspicion of MPD* } \\
\hline & & $\begin{array}{c}\text { Yes } \\
\text { n (\%) }\end{array}$ & $\begin{array}{c}\text { No } \\
\text { n }(\%)\end{array}$ \\
\hline \multicolumn{4}{|l|}{ Gender } \\
\hline Female & $74(82.2)$ & $25(27.7)$ & $49(62.1)$ \\
\hline Male & $16(17.8)$ & $4(25)$ & $12(75)$ \\
\hline \multicolumn{4}{|l|}{ Age group (years) } \\
\hline $\begin{array}{l}26 \text { to } 34 \\
35 \text { to } 44 \\
45 \text { to } 54 \\
>54\end{array}$ & $\begin{array}{l}14(15.6) \\
23(25.6) \\
30(33.3) \\
23(25.5)\end{array}$ & $\begin{array}{l}5(35.8) \\
7(30.4) \\
8(26.7) \\
9(39.1)\end{array}$ & $\begin{array}{l}9(64.2) \\
16(69.6) \\
22(73.3) \\
14(60.9)\end{array}$ \\
\hline \multicolumn{4}{|l|}{ Marital status } \\
\hline $\begin{array}{l}\text { Single } \\
\text { Married/common- } \\
\text { law marriage } \\
\text { Divorced } \\
\text { Widow(er) }\end{array}$ & $\begin{array}{c}30(33.3) \\
40(44.4) \\
14(15.6) \\
6(6.7)\end{array}$ & $\begin{array}{c}13(43.3) \\
8(20) \\
5(35.7) \\
3(50)\end{array}$ & $\begin{array}{c}17(56.7) \\
32(80) \\
9(64.3) \\
3(50)\end{array}$ \\
\hline \multicolumn{4}{|l|}{ Function } \\
\hline $\begin{array}{l}\text { Nurse } \\
\text { Nursing } \\
\text { technician } \\
\text { Nursing aide }\end{array}$ & $\begin{array}{c}18(20) \\
60(66.7) \\
12(13.3)\end{array}$ & $\begin{array}{l}10(55.6) \\
16(26.7) \\
3(25)\end{array}$ & $\begin{array}{c}8(44.4) \\
44(73.3) \\
9(75)\end{array}$ \\
\hline \multicolumn{4}{|l|}{ Level of education } \\
\hline $\begin{array}{l}\text { Higher education } \\
\text { High school }\end{array}$ & $\begin{array}{l}44(48.9) \\
46(51.1)\end{array}$ & $\begin{array}{l}17(38.6) \\
12(26)\end{array}$ & $\begin{array}{c}27(61.4) \\
34(74)\end{array}$ \\
\hline \multicolumn{4}{|l|}{ Family income } \\
\hline $\begin{array}{l}1 \text { to } 2 \text { minimum } \\
\text { wages }\end{array}$ & $18(20)$ & $2(11.1)$ & $16(88.9)$ \\
\hline $\begin{array}{l}3 \text { to } 5 \text { minimum } \\
\text { wages }\end{array}$ & $41(45.6)$ & $14(34)$ & $27(66)$ \\
\hline $\begin{array}{l}>5 \text { minimum } \\
\text { wages }\end{array}$ & $21(23.4)$ & $13(61.9)$ & $8(38.1)$ \\
\hline \multicolumn{4}{|l|}{ Contract type } \\
\hline $\begin{array}{l}\text { Statutory } \\
\text { CLT } \\
\text { Temporary }\end{array}$ & $\begin{array}{c}44(48.9) \\
43(47.8) \\
3(3.3)\end{array}$ & $\begin{array}{l}18(40.9) \\
9(21) \\
2(2.2)\end{array}$ & $\begin{array}{l}26(59.1) \\
34(79) \\
1(33.3)\end{array}$ \\
\hline \multicolumn{4}{|l|}{ Has another job } \\
\hline $\begin{array}{l}\text { Yes } \\
\text { No }\end{array}$ & $\begin{array}{l}48(53.3) \\
42(46.7)\end{array}$ & $\begin{array}{l}17(35.4) \\
10(23.8)\end{array}$ & $\begin{array}{l}31(64.6) \\
28(76.2)\end{array}$ \\
\hline \multicolumn{4}{|l|}{ Daily working hours } \\
\hline $\begin{array}{l}6 \text { hours } \\
12 \text { hours/day } \\
12 \text { hours/night }\end{array}$ & $\begin{array}{c}7(7.8) \\
39(43.3) \\
44(48.9)\end{array}$ & $\begin{array}{c}3(42.9) \\
\quad 7(18) \\
19(43.1)\end{array}$ & $\begin{array}{c}4(57.1) \\
32(82) \\
25(56.9)\end{array}$ \\
\hline \multicolumn{4}{|c|}{ Weekly working hours } \\
\hline $\begin{array}{l}30 \text { hours } \\
40 \text { hours }\end{array}$ & $\begin{array}{l}64(71.1) \\
26(28.9)\end{array}$ & $\begin{array}{l}21(33) \\
8(30.8)\end{array}$ & $\begin{array}{c}43(67) \\
18(69.2)\end{array}$ \\
\hline \multicolumn{4}{|l|}{ Total working hours } \\
\hline $\begin{array}{l}>50 \text { hours } \\
<50 \text { hours }\end{array}$ & $\begin{array}{l}52(57.8) \\
38(42.2)\end{array}$ & $\begin{array}{c}21(40.3) \\
8(21)\end{array}$ & $\begin{array}{c}31(59.7) \\
30(79)\end{array}$ \\
\hline
\end{tabular}

*MPD: minor psychic disorders. Note: $\mathrm{n}=90$.

When asked about the self-evaluation of health conditions, treatments, and sick leaves, $44.4 \%$ of the participants reported that they had some type of diagnosed disease, such as high blood pressure, diabetes, musculoskeletal or respiratory disorders, and anxiety, in addition to taking medication regularly. Despite the health issues, only $15.5 \%$ declared that they took sick leaves over the 12 months that preceded data collection.
Table 2 - Distribution of nursing workers according to the group of symptoms and affirmative answers in the SRQ-20 - Rio de Janeiro, RJ, Brazil, 2018.

\begin{tabular}{|c|c|c|}
\hline \multirow{2}{*}{ SRQ-20 factors* } & Yes & No \\
\hline & n (\%) & n (\%) \\
\hline \multicolumn{3}{|l|}{ Factor 1 - Anxious depressive humor } \\
\hline Do you feel nervous, tense, or worried? & $46(51.1)$ & $44(48.9)$ \\
\hline Are you easily frightened? & $26(28.9)$ & $64(71.1)$ \\
\hline Do you feel unhappy lately? & $23(25.5)$ & $67(74.5)$ \\
\hline Do you cry more than usual? & $13(14.4)$ & $77(85.6)$ \\
\hline \multicolumn{3}{|l|}{ Factor II - Reduction in vital energy } \\
\hline Are you easily tired? & $18(20)$ & $72(80)$ \\
\hline Do you find it difficult to make decisions? & $24(26.7)$ & $66(73.3)$ \\
\hline $\begin{array}{l}\text { Do you find it difficult to enjoy your } \\
\text { daily activities? }\end{array}$ & $25(27.8)$ & $65(72.2)$ \\
\hline Do you have trouble thinking clearly? & $23(25.5)$ & $67(74.5)$ \\
\hline Is your daily work suffering? & $34(37.8)$ & $56(62.2)$ \\
\hline You feel tired all the time. & $27(30)$ & $63(70)$ \\
\hline \multicolumn{3}{|l|}{ Factor III - Somatic symptoms } \\
\hline $\begin{array}{l}\text { Do you have uncomfortable feelings in } \\
\text { your stomach? }\end{array}$ & $33(36.7)$ & $57(63.3)$ \\
\hline Is your appetite poor? & $12(13.3)$ & $78(86.7)$ \\
\hline Do you often have headaches? & $37(41.1)$ & $53(58.9)$ \\
\hline Do you sleep badly? & $11(12.2)$ & $79(87.8)$ \\
\hline Is your digestion poor? & $28(31.1)$ & $62(68.9)$ \\
\hline Do your hands shake? & $25(27.8)$ & $65(72.2)$ \\
\hline \multicolumn{3}{|l|}{ Factor IV - Depressive thoughts } \\
\hline Have you lost interest in things? & $5(5.6)$ & $85(94.4)$ \\
\hline Are you unable to play a useful part in life? & $20(22.2)$ & $70(77.8)$ \\
\hline $\begin{array}{l}\text { Do you feel that you are a worthless } \\
\text { person? }\end{array}$ & $3(3.3)$ & 87 (96.7) \\
\hline $\begin{array}{l}\text { Has the thought of ending your life been } \\
\text { in your mind? }\end{array}$ & $1(1.1)$ & 84 (98.9) \\
\hline
\end{tabular}

\section{DISCUSSION}

The suspicion of MPD found in the present study was $32.2 \%$, a result similar to that reported in a study carried out with nursing workers at a general hospital in Bahia, Brazil, which found a rate of $35 \%$. The suspicion was associated with work overload, the existence of more than one employment bond, low remuneration, temporary or precarious work contracts, and health problems related to body posture and mental health ${ }^{(8)}$. In another study involving nursing workers $(\mathrm{n}=335)$ allocated at emergency, intensive care, and inpatient units at a hospital in Porto Alegre, Rio Grande do Sul state, Brazil, the suspicion was equal to $20.6 \%$, and the MPD were associated with stress resulting from the high psychological demand and fatigue at work ${ }^{(2)}$.

When correlating MPD suspicion data with sociodemographic characteristics (Table 1) in bivariate analysis, the highest suspicion frequencies were found for nursing technicians, women, single professionals, older than 54 years, with higher education and a family income between three and five minimum wages. A study on absenteeism in nursing with 1,378 participants showed that nursing technicians were more likely to get sick and be away from work. The result can be explained by the fact that nursing workers account for the highest number of health professionals and 
usually their activities require greater physical efforts and an intense work rhythm ${ }^{(9)}$.

A study that examined the prevalence of MPD in healthcare workers $(n=4,749)$ at Basic Units in the South and Northeast regions in Brazil obtained a suspicion of $16 \%$ in the sample. "However, the difference was statistically significant among the professional categories $(p<0.001)$, with the suspicion being lower in professionals with a university degree and higher in community health agents and other workers with a high school degree $(18 \%)$, with nursing professionals (14.6\%) and physicians (15\%) at an intermediate situation. The prevalence of MPD did not show statistically significant differences concerning gender, income, and smoking habits"(10). The occurrence decreased significantly when associating satisfaction with structure, "teamwork, and meetings with the community"(10).

A study that applied the Brazilian Mental Health Services' Satisfaction Scale (IMPACTO-BR), which evaluates the overload felt by mental healthcare professionals as a consequence of daily work, associated the work impact with some sociodemographic and occupational characteristics in the sample, with a prevalence of: women, complete high school, work carried out in shifts, and a shorter time working in the institution. Professionals between 25 and 39 years old showed a higher impact on their health when faced with the intensification of feelings such as frustration, overload, stress, depression, and feeling tired after work ${ }^{(11)}$.

Regarding level of education, the results of the present study agree with those reported in an investigation that showed a weaker association of MPD with people with a university degree. A higher level of education increases the chances of better opportunities in life, in addition to influencing aspirations and self-esteem, subjective factors that can motivate people to take attitudes and lead to the adoption of health-protective behaviors ${ }^{(12)}$. Concerning age group, mental health problems, such as depression, affect a higher number of people in the group of younger nursing professionals in comparison with older workers, whose cognitive, emotional, and physical maturity provides them with confidence to solve problems and cope with adversities ${ }^{(13)}$.

Regarding gender, studies involving health workers have associated the "female gender with MPD"(2,8-11). Among the nursing professionals who worked at a hospital, logistic regression analysis showed that "women had a 2.36 higher probability to have MPD and, among those younger than 39 years, the chances were 2.21 times higher" ${ }^{(3)}$.

Regarding occupational characteristics, bivariate statistical analysis indicated a higher frequency of MPD in association with the following independent variables: night work, double employment bond, and more than 50 weekly working hours when taking into account the other employment bonds. Concerning the shifts, there was a statistically significant association ( $p=0.003$ ) of MPD with night work, and the professionals who carried out their activities in that shift had a probability of suspicion of MPD three times higher than professionals who worked in more than one shift ${ }^{(2)}$. A study with 359 health professionals who worked at a federal hospital identified that the prevalence of MPD was associated with some occupational characteristics in workers who had more than one employment bond, whose weekly working hours exceeded 54, and worked in a shift regimen ${ }^{(3)}$.

Although parametric tests were not performed to establish the association of MPD with chronic diseases in the sample, it is inferred that those health issues must be considered, because $44.4 \%$ of the participants with suspicion reported that they had high blood pressure, diabetes, musculoskeletal or respiratory disorders, and anxiety. Additionally, they took medication regularly. A study with the objective to identify MPD in users of Basic Health Units and establish the association with the sociodemographic and pharmacotherapeutic profile revealed the correlation between suspicion and the use of medication and chronic comorbidities such as high blood pressure and diabetes ${ }^{(12)}$.

Regarding the symptoms predictive of MPD in the sample, a prevalence of Factor I was verified (anxious depressive humor) in the question "Do you feel nervous, tense, or worried?" in $51.1 \%$ of the participants (Table 2). This is a prevalent complaint in several studies with healthcare professionals that applied the SRQ-20 $0^{(4,8-9,13)}$. It is important to consider the relevance of the symptoms shown by the workers which, in addition to pointing out to distress, can interfere with the working process, especially when the adverse effects on patients receiving nursing care are taken into account. There is also the relational nature of the profession, because the accumulated tension may lead to tension and nervousness and contribute to the development of conflicts in interpersonal relationships between users and the other team components ${ }^{(2)}$.

Concerning Factor II (Reduction in vital energy), the question "Is your daily work suffering?" indicated one of the most frequent complaints, with $37.8 \%$ affirmative answers. This result is similar to that reported in a study that evaluated the physical and psychic loads of the nursing work at a psychiatric hospital, revealing distress through the complaints of stress, physical and mental tiredness, body aches, anxiety, and fatigue. The consequences of the work-health-disease process were related to the care provided to patients who had psychomotor agitation, were bedridden, sedated and/or restrained, and were intensified by the risk the workers were exposed to regarding patients' violence, mainly during psychiatric emergencies ${ }^{(5)}$.

A longitudinal and cross-sectional study carried out in Taiwan on suspicion of MPD ( $\mathrm{n}=19,641)$ including dentists, nurses, physicians, pharmacists, occupational therapists, nutritionists, speech therapists, and veterinarians showed that the prevalence of suspicion in the sample was higher when compared to that found for workers from other fields. Minor psychic disorders were associated with the following characteristics: work in a shift regimen, longer time working in the institution, higher psychological demands, occupational violence and feeling of injustice ${ }^{(14)}$. Health professionals exposed to violence at work showed a suspicion of MPD equal to $63.7 \%$, with the prevalence of the variables female gender, young workers, lower level of education, and the functions of nursing technicians or aides. Among the victims, $35 \%$ suffered some type of violence and $28.2 \%$ were 
exposed to two or more forms of violence. A significant association was found between MPD and exposure to multiple forms of violence in $17.1 \%$ of the participants ${ }^{(15)}$.

Another study on nursing work-related violence with a sample of 521 nurses at a hospital in Taiwan found that $51.4 \%$ were physically assaulted, $29.8 \%$ were verbally assaulted, and $12.9 \%$ were sexually abused. Logistic regression analysis verified the association between violence and anxiety in workers up to 30 years old and those who worked in the night shift ${ }^{(16)}$.

Regarding Factor III (Somatic symptoms), the complaints "Do you often have headaches?" and "Do you have uncomfortable feelings in your stomach?" prevailed. These findings corroborate the results of a study carried out with nurses that worked as professors at federal universities in the South region of Brazil. In this investigation, the SRQ-20 questions that received more affirmative answers were: "Do you feel nervous, tense, or worried?" (49.2\%), "Do you sleep badly?" (39.2\%), "Are you easily tired?" (37.7\%), "Do you often have headaches?" (34.6\%), and "Do you find it difficult to enjoy your daily activities?” $(30.8 \%)^{(17)}$.

Concerning Factor IV (Depressive thoughts), the complaints that showed the highest frequency of affirmative answers were "Are you unable to play a useful part in life?" and "Have you lost interest in things?". A study that applied the Beck Depression Inventory, the Hamilton Depression Rating Scale, and the Montgomery-Asberg Depression Rating Scale in a sample of nurses made up of $91.53 \%$ of women detected the prevalence of depression in $40.67 \%$ of the participants. Despite the results, the examined nurses did not believe or did not want to admit having depressive symptoms, although $92.3 \%$ of the sample had already gone through some type of treatment in the mental health field ${ }^{(18)}$.

There are factors internal and external to people that can be associated with depressive reactions or contribute to the development of depression, including a higher genetic vulnerability, some personality characteristics, and the susceptibility to situational events related to the physical and social work environment. Nursing professionals, especially those who work in hospital settings, face situations that can boost depressive reactions, such as the death of patients who were under the team's care, little autonomy, lack of recognition, work overload, insecurity, conflicts of interest, and reduced social support ${ }^{(19)}$.

A study that evaluated the suspicion of MPD and depression in health professionals who worked at CAPS and the Family Health Strategy identified that, among the 119 analyzed mental health professionals, the prevalence of suspicion of MPD and depression was $25.2 \%$ and $23.5 \%$, respectively. The study concluded that CAPS professionals were more adapted to the work demands, given that less health harm caused by work was found in that group ${ }^{(20)}$.
A study showed that the main causes of sick leaves by public servants are mental disorders resulting from depressive episodes, reactions to severe stress related to adaptation disorders, and the use of psychoactive substances. The results agree with data reported by the $\mathrm{WHO}$ when predicting the increase in the prevalence of mental disorders in the population in general. Consequently, it is necessary to consider the emotional, social, and financial costs of these disorders for the people who develop them and the society, as well as the relevance of public policies oriented toward their prevention and treatment ${ }^{(21)}$.

The results obtained in the present study must be analyzed from the perspective of some theoretical-methodological limitations, given that it is a cross-sectional investigation that evaluates only the relationship between the variables, with neither a definition nor an establishment of a causal link. The sample, despite being representative of the population of nursing professionals who worked at the hospital, was limited to a single institution, which may have contributed to the high frequency of suspicion of MPD.

Although it is impossible to generalize the results for other work contexts, the findings reinforce those described in other studies in different mental health contexts, because studies of this nature with nursing workers at psychiatric hospitals were not identified. The authors stress the importance of continuing the studies in this field, to estimate the prevalence of early suspicion of MPD and the association with sociodemographic and professional variables so it is possible to reinforce the relevance of measures that minimize the risks of evolution of these disorders into severe psychiatric conditions.

\section{CONCLUSION}

The suspicion of MPD in $32.2 \%$ of the sample is a worrying result and significantly higher in comparison with that observed in studies carried out with health professionals. In the group of signs and symptoms predictive of MPD, there was a higher frequency of decrease in vital energy and indications of somatization, respectively, whose symptoms may be related to stress and psychophysical fatigue of people who deal with patients with mental disorders.

The relationship between occupational characteristics and the higher frequency of suspicion of MPD is an aspect to be analyzed by managers and institutions, so they can know, reflect on, and identify the implications of occupational risk factors for mental health and the work of nursing professionals at psychiatric hospitals. There is the need for preventive and therapeutic actions in that group of workers and for strengthening effective coping strategies in face of the severity of the symptoms in the development of serious mental disorders, which may lead to negative consequences for people's personal, social, and professional life.

\section{RESUMO}

Objetivo: Descrever a frequência de suspeição de distúrbios psíquicos menores e os sintomas em trabalhadores de Enfermagem de um hospital psiquiátrico. Método: Estudo transversal realizado em $2018 \mathrm{com}$ trabalhadores de Enfermagem de um hospital psiquiátrico na cidade do Rio de Janeiro. Os dados foram coletados por meio de um instrumento com variáveis sociodemográficas, laborais e de saúde. Para a verificação dos distúrbios psíquicos menores utilizou-se o Self Report Questionnaire-20. Resultados: Participaram 90 
trabalhadores. A frequência de distúrbios psíquicos menores na amostra foi de 32,2\%. As questões com maiores frequências de respostas afirmativas foram: "Sente-se nervoso(a), tenso(a) ou preocupado(a)" (51,1\%), "Tem dores de cabeça frequentes" (41,1\%), "Seu trabalho lhe causa sofrimento" (37,8\%), "Você sente desconforto estomacal" (36,7\%), "Tem dificuldades de ter satisfação em suas tarefas" (27,8\%) e "É incapaz de desempenhar um papel útil em sua vida" $(22,2 \%)$. Conclusão: A predominância de sintomas de diminuição da energia vital e somatização sugerem estresse e risco de transtorno mental.

\section{DESCRITORES}

Enfermagem Psiquiátrica; Transtornos Mentais; Estresse Psicológico; Saúde do Trabalhador; Saúde Mental.

\section{RESUMEN}

Objetivo: Describir la frecuencia de suspección de trastornos psíquicos menores y los síntomas en trabajadores de Enfermería de un hospital psiquiátrico. Método: Estudio transversal, realizado en 2018 con trabajadores de Enfermería de un hospital psiquiátrico en la ciudad de Río de Janeiro. Los datos fueron recogidos mediante un instrumento con variables sociodemográficas, laborales y de salud. Para la verificación de los trastornos psíquicos menores se utilizó el Self-Reporting Questionnaire-20. Resultados: Participaron 90 trabajadores. La frecuencia de trastornos psíquicos menores en la muestra fue del 32,2\%. Las preguntas con mayores frecuencias de respuestas afirmativas fueron: "Se siente nervioso/a, tenso/a o preocupado/a" (51,1\%), "Tiene dolores de cabeza frecuentes" (41,1\%), "Le causa sufrimiento su trabajo" (37,8\%), "Siente usted incomodidad estomacal" (36,7\%), "Tiene dificultades de tener satisfacción en sus tareas" (27,8\%) y "Es incapaz de desempeñar un papel útil en su vida" (22,2\%). Conclusión: La predominancia de síntomas de disminución de la energía vital y somatización sugieren estrés y riesgo de trastorno mental.

\section{DESCRIPTORES}

Enfermería Psiquiátrica; Trastornos Mentales; Estrés Psicológico; Salud Laboral; Salud Mental.

\section{REFERENCES}

1. Beusenberg M, Orley JH; World Health Organization, Division of Mental Health. A user's guide to the self reporting questionnaire (SRQ) [Internet]. Geneva: WHO; 1994 [cited 2018 jun 20]. Available from: https://apps.who.int/iris/handle/10665/61113

2. Urbaneto JS, Magalhães MCC, Maciel VO, Sant'Anna VM, Gustavo AS, Figueiredo CEP, et al. Work-related stress according to the demandcontrol and minor psychic disorders in nursing workers. Rev Esc Enferm USP [Internet]. 2013 [cited 2017 Apr 21];47(3):1186-93. Available from: http://www.scielo.br/scielo.php?script=sci_arttext\&pid=S0080-62342013000501180

3. Alves AP, Pedrosa LAK, Coimbra MAR, Miranzi MAS, Hass VJ. Prevalência de transtornos mentais comuns entre profissionais de saúde. Rev Enferm UERJ. 2015;23(1):64-9.

4. Souza SRC, Oliveira EB, Mauro MYC, Mello R, Kestemberg CCF, Paula GS. Cargas de trabalho de enfermagem em unidade de internação psiquiátrica e a saúde do trabalhador. Rev Enferm UERJ [Internet]. 2015 [citado 2018 jul. 10];23(5):633-8. Disponível em: http://www. facenf.uerj.br/v23n5/v23n5a09.pdf

5. Athayde V, Hennington EA. A saúde mental dos profissionais de um Centro de Atenção Psicossocial. Physis [Internet]. 2012 [citado 2018 jul. 20];22(3):983-1001. Disponível em: http://www.scielo.br/pdf/physis/v22n3/08.pdf

6. Mari JJ, Willians P. A validity study of a psychiatric screening questionnaire (SRQ-20) in primary care in the city of São Paulo. Br J Psychiatric. 1986;148(1):23-6. DOI: 10.1192/bjp.148.1.23

7. Gonçalves DM, Stein AT, Kapczinski F. Avaliação de desempenho do Self-Reporting Questionnaire como instrumento de rastreamento psiquiátrico: um estudo comparativo com o Structured Clinical Interview for DSM-IV-TR. Cad Saúde Pública [Internet]. 2008 [citado 2018 maio 14];24(2):380-90. Disponível em: http://www.scielo.br/scielo.php?script=sci_arttext\&pid=S0102-311X2008000200017

8. Pereira RE, Rodrigues US, Oliveira LMM, Laudano RCS, Nascimento Sobrinho CL. Prevalência de transtornos mentais comuns em trabalhadores de enfermagem em um hospital da Bahia. Rev Bras Enferm. 2015;67(2):296-301.

9. Trindade LL, Grisa CC, Ostrovski VP, Adamy EK, Ferraz L, Amestoy SC, et al. Absentismo en el equipo de enfermería en el ambiente hospitalário. Enferm Global [Internet]. 2014 [citado 2018 Jul 7];13(36):146-75. Disponible en: https://revistas.um.es/eglobal/article/view/ eglobal.13.4.181541/165931

10. Dilelio AS, Facchini AL, Tomasi E, Silva MS, Thumé E, Piccini XR, et al. Prevalência de transtornos psiquiátricos menores em trabalhadores da atenção primária à saúde das regiões Sul e Nordeste do Brasil. Cad Saúde Pública [Internet]. 2012 [citado 2018 jun. 12];28(3):503-14. Disponível em: http://www.scielo.br/scielo.php?script=sci_arttext\&pid=S0102-311X2012000300011

11. Moura GA, Roncalli AG, Noro LRA. Impacto do trabalho em profissionais de Serviços de Saúde Mental em um município do Nordeste Brasileiro Ciênc Prof [Internet]. 2016 [citado 2018 maio 10];36(2):401-10. Disponível em: http://www.scielo.br/pdf/pcp/v36n2/19823703-pcp-36-2-0401.pdf

12. Gomes VF, Miguel TLB, Miasso Al. Common mental disorders: socio-demographic and pharmacotherapy profile. Rev Latino Am Enfermagem [Internet]. 2013 [cited 2018 June 12];21(6):1203-11. Available from: http://www.scielo.br/scielo.php?script=sci_arttext\&pid=S0102311 X2012000300011

13. Silva DSD, Tavares NVS, Alexandre ARG, Freitas DA, Brêda MZ, Albuquerque MCS, et al. Depression and risk of suicide in professional nursing: integrative review. Rev Esc Enferm USP [Internet]. 2015 [cited 2018 Apr 6];49(6):1027-36. Available from: http://www.scielo.br/ scielo.php?script=sci_arttext\&pid=S0080-62342015000601023

14. Cheng WJ, Cheng Y. Minor mental disorders in Taiwanese healthcare workers and the associations with psychosocial work conditions. J Formos Med Assoc. 2017;116:300-5.

15. Pai DD, Lauter L, Souza SBC, Marziale MHP, Tavares JP. Violence, burnout and minor psychiatric disorders in hospital work. Rev Esc Enferm USP [Internet]. 2015 [cited 2018 July 26];49(3):460-8. Available from: http://www.scielo.br/scielo.php?script=sci_arttext\&pid $=$ S0080-62342015000300457

16. Pai HC, Lee S. Risk factors for workplace violence in clinical registered nurses in Taiwan. J Clin Nurs. 2011;20:1405e12. 
17. Tavares JP, Magnago TSBS, Beck CLC, Silva RM, Prestes FC, Lautert L. Prevalence of minor psychiatric disorders in nursing professors. Esc Anna Nery [Internet]. 2014 [cited 2018 may 12];18(3):407-14. Available from: http://www.scielo.br/pdf/ean/v18n3/en_1414-8145ean-18-03-0407.pdf

18. Fernandes DM, Marcolan JF. Trabalho e sintomatologia depressiva em enfermeiros da Estratégia de Saúde da Família. SMAD Rev Eletr Saúde Mental Álcool Drogas [Internet]. 2017 [citado 2018 jul. 24];13(1):37-4. Disponível em: http://pepsic.bvsalud.org/scielo.php?script=sci_ arttext\&pid=S1806-69762017000100006\&lng=pt\&nrm=iso\&tlng=pt

19. Martins JT, Ribeiro RP, Remijo KP, Ribeiro PHV. Mental disorders linked to the nursing work. Rev Enferm UFPE Online [Internet]. 2014 [cited 2018 Feb 21];8(6):1746-56. Available from: https://periodicos.ufpe.br/revistas/revistaenfermagem/article/view/13650

20. Knuth BS, Silva RA, Oses JP, Radtke VA, Cocco RA, Jansen K. Transtornos mentais comuns em trabalhadores da Atenção Básica à Saúde. Rev Bras Saude Ocup [Internet]. 2016 [citado 2018 maio 08];20(8):1413-23. Disponível em: http://www.scielo.br/scielo.php?script=sci_ar ttext\&pid=S0303-76572016000100210

21. Oliveira LA, Baldaçara LR, Maia MZB. Afastamentos por transtornos mentais entre servidores públicos federais no Tocantins. Rev Bras Saúde Ocup [Internet]. 2015 [citado 2018 maio 12];40(132):156-69. Disponível em: http://www.scielo.br/scielo.php?script=sci_ arttext\&pid=S0303-76572015000200156\&lng=en\&nrm=iso\&tlng=pt 